\title{
WRITING APPREHENSION IN THE WRITING CLASS: INDONESIAN EFL LEARNERS CONTEXT
}

\author{
Hanna Sundari ${ }^{1}$, Rina Husnaini Febriyanti ${ }^{2}$ \\ Indraprasta PGRI University \\ hanna.sundari@gmail.com febri_usagi@yahoo.com
}

\begin{abstract}
The aims of Writing Apprehension in the Writing Class: Indonesian EFL Learners Context research is to find out the correlation between writing apprehension towards students' writing skill. The research was located in Universitas Indraprasta PGRI. This research was held from August 2015 to January 2016. The method of this research was quantitative approach using survey method. The respondents were the students who took writing subject that consist of three classes; meanwhile the number of samples was 66 students who were chosen randomly. And the instruments are questionnaire by Cheng (2004) namely The Second Language Writing Anxiety Inventory (SLWAI) and English writing test. The data was analyzed quantitatively by using SPSS 17.0. The research result showed that writing performance was seemingly good with 72 average score; meanwhile, writing apprehension scored 69.98 which indicate that the students apparently do not feel very anxious during writing the paper. Moreover, the tscore (-1.22) and the significant score (0.0311) were very on top of the sig. score (0.05). That can be said that $H_{0}$ is accepted and $H_{a}$ is rejected. We can draw a conclusion that there is no significant correlation between writing apprehension and writing performance for academic writing in higher education level.
\end{abstract}

\begin{abstract}
Abstrak
Tujuan penelitian ini untuk mengetahui hubungan antara kecemasan menulis terhadap keterampilan menulis siswa. Penelitian dilakukan di Universitas Indraprasta PGRI dari Agustus 2015 sampai Januari 2016. Penedekatan penelitian yang digunakan adalah kuantitatif dengan metode survey. Responden adalah mahasiswa yang mengikuti kelas Writing sebanyak 66 mahasiswa. Instrumen terdiri dari kuesioner yang merujuk pada Cheng (2004) yakni The Second Language Writing Anxiety Inventory (SLWAI) dan tes menulis bahasa Inggris. Data dianalisis dengan dibantu SPSS 17.0. Hasil penelitian menunjukkan bahawa performansi keterampilan menulis mahasiswa berada pada kategori baik dengan skor 72; sementara skor kecemasan menulis ada diposisi 69.98 yang menunjukkan bahwa mahasiswa tampaknya tidak terlalu cemas selama aktivitas menulis. Selanjutnya, nilai t (-1.22) dan nilai sig (0.0311). Dengan demikian, hipotesis alternatif yang rumuskan ditolak. Sehingga tidak ada korelasi yang signifikan antaa kecemasan menulis dengan performansi menulis khususnya bagi mahasiswa di tingkat perguruan tinggi.
\end{abstract}

\section{INTRODUCTION}

Writing, as a productive skill, is considered to be the most complex and difficult activity particularly for learners in EFL/ESL context. Writing is both a challenging discipline and the singly most difficult aspect of English language acquisition (Jahin, 2012). The learners should experience plentiful writing process (pre-, whilst, post-) such as deciding topic, brainstorming ideas, making outline, writing first draft, then editing it, and re-writing final draft (Oshima and Hogue, 2006). At the same time, the students have to negotiate some criteria like mechanics, grammar convention, vocabulary, and diction on target language (Shah et al, 2011: 8). Moreover, in writing class, some teachers or lecturers often give negative feedback as the learners make mistakes on their sheets. Besides, they also write negative comments instead of positive one. These may diminish learners' 
motivation and effort to try more for next writing task. As a result, the complex process of writing, a set of criteria on writing evaluation and negative feedback given by teachers/lecturer may probably cause anxiety when writing. Writing anxiety here can be defined as "a fear of writing process that outweighs the projected gain from the ability to write" (Thompson in Jahin, 2012: 6061).

Furthermore, studies have shown that apprehension on writing is closely related to writing performance. Al Sawalha et al (2012: 7) investigated writing-anxiety in Jordanian EFL students and wrote that the quality of writing performance can be predicted by the effect of writing apprehension. Then Al Sawalha et al also discovered that low level of apprehension tends to achieve higher grades in composition courses. And the causes vary from learner's ability to the fear of teachers' judgments. Lastly, this research aimed to ascertain the level of writing apprehension of Indonesian EFL learners and to find out whether writing apprehension is negatively related to writing performance or not.

\section{LITERATURE REVIEW}

In Indonesian EFL context, writing is one of major component of EFL instruction. It is gradually learnt from primary schools to higher education. On high schools both junior and senior, learners have to be able to communicate either oral or written in English. It is as the first and major competence in the scope of English instruction at schools. On higher education, written assignments are given to pursuit academic goals. In fact, most of the learners call writing impediment. Some causes make writing as difficult activity are probably learner's ability, ideas and plan, time constraint, teacher's comment and learner's fear (Al_Sawalha, Salem, Chow, \& Foo, 2012). The fear of writing is also known as writing-specific anxiety or writing apprehension.

Indeed, the idea about writingspecific anxiety and the term "writing apprehension" in first language writing was coined firstly by Daly and Miller in 1970s (Al_Sawalha et al, 2012; Jahin, 2012). Then, Cheng also developed Second language Writing Apprehension Inventory (SLWAI) for EFL context (Cheng, 2004). This instrument has been widely used particularly where English is as second or foreign language to measure the degree of learner's anxiety in writing. However, writing anxiety refers to a "situation and subject specific individual difference associated with a person's tendencies to approach or avoid situation perceived to potentially require writing accompanied by some amount of perceived evaluation." (Al_Sawalha, Salem, Chow, \& Foo, 2012). Likewise, Bloom (in Al_Sawalha et al, 2012) defines writing anxiety as " $a$ label for one or a combination of feeling, beliefs, or behaviors that interfere with a person' ability to start, work on, or finish a given writing task that s/he is intellectually capable of doing." Shortly speaking, writing apprehension is a psychological situation faced by an individual dealt with writing task and affects writing process and performance.

Furthermore, numerous researches have been devoted to investigate the relation between writing apprehension and writing performance. The result findings showed that writing apprehension is mostly negatively related to writing performance in English as second or foreign language instruction. Study in Malaysia by Al_Sawalha et al noted that EFL students experienced high level of writing apprehension. They find writing to be unrewarding and will avoid classes 
that give writing task (Al_Sawalha, Salem, Chow, \& Foo, 2012). Then, Takahashi's research in Japan wrote that students with better writing skills, who probably experienced lower levels of writing anxiety, had higher overall English proficiency; then they have also scored higher in the final examination. It can be drawn a conclusion that writing apprehension was found to be negatively related to class achievement/proficiency for Japanese EFL students (Takahashi: 2010). Similarly, Parina and de Leon (2013) added several researches about the effects of writing apprehension around Asia. Study by Erkan and Saban (2011) in Turkey showed that it directly affects writing performance. Besides, that writing apprehension, together with writing self-efficacy, affects writing proficiency level is also investigated for ESL students in Malaysia by Sing and Rajalinglam (2010, dalam Parina \& de Leon, 2013).

Then, there have been many researches try to find out the causes of apprehension or anxiety in writing. Firstly, teacher's feedback may affect much to the writer's motivation and confidence. Dali and Wilson (1983) said that positive comments given by the teachers develop positive attitude; in contrast Daly (1978) also noted negative comments ended up with reduced confidence, reinforcement and satisfaction. Time constraint may put the second position of the causes of anxiety. When the writers have limited time to process their writing task including pre, whilst, and post; they tend to be over worried and anxious. The others are they are not able to negotiate set of criteria, such as mechanics, vocabulary, grammar convention, and diction on target language (Al_Sawalha, Salem, Chow, \& Foo, 2012). The causes may put the students suffer writing anxiety.

\section{RESEARCH METHOD}

This study aimed to investigate the relationship between writing apprehension and writing performance in writing class. As a result, the research questions are:

1. What are the levels of writing apprehension of Indonesian EFL learners in writing class?

2. Is there any negative correlation between writing apprehension and writing performance for Indonesian EFL learner in writing class?

To find the answer of the questions above, this research carried two instruments. First, it was questionnaire by Cheng (2004) namely The Second Language Writing Anxiety Inventory (SLWAI). It contains 22 items with five options Likert Scale ranging from "strongly agree" to "strongly disagree." The second instrument was the essay writing test. The students choose the topics freely. Then, the essays were assessed by a checklist of writing assessment rubric. The criteria would be evaluated on the essays are content, organization, grammar and sentence structures and mechanics based on writing rubric by Alice Oshima and Ann Hogue. The participants on this research were taken from the students on Writing III. They were 66 respondents. Data was analyzed quantitatively by using SPSS 17.0.

\section{RESULT AND DISCUSSION}

This present research purposes to figure out the correlation of writing apprehension and writing performance particularly in higher education level. The data were taken from two instruments: questionnaire and writing test. The description for writing performance is displayed below. 


Statistics
WRITING PERFROMANCE
\begin{tabular}{|l|r|}
\hline \multicolumn{1}{|c|}{ Valid } & 66 \\
& Missing \\
Mean & 0 \\
Median & 72.89 \\
Mode & 73.00 \\
Std. Deviation & 80 \\
Variance & 6.409 \\
Range & 41.081 \\
Minimum & 21 \\
Maximum & 63 \\
Sum & 84 \\
\hline
\end{tabular}

On the data table above it can be seen from 66 data responders the average score is 72,89 , and median score is 73.00 and for the modus score is 80 , the highest score is 84 and the lowest score is 63 so that it can be range 21 and standard deviation is6,409 and variance score is 41.081. By this assumption it can be seen in histogram graphic as follows:

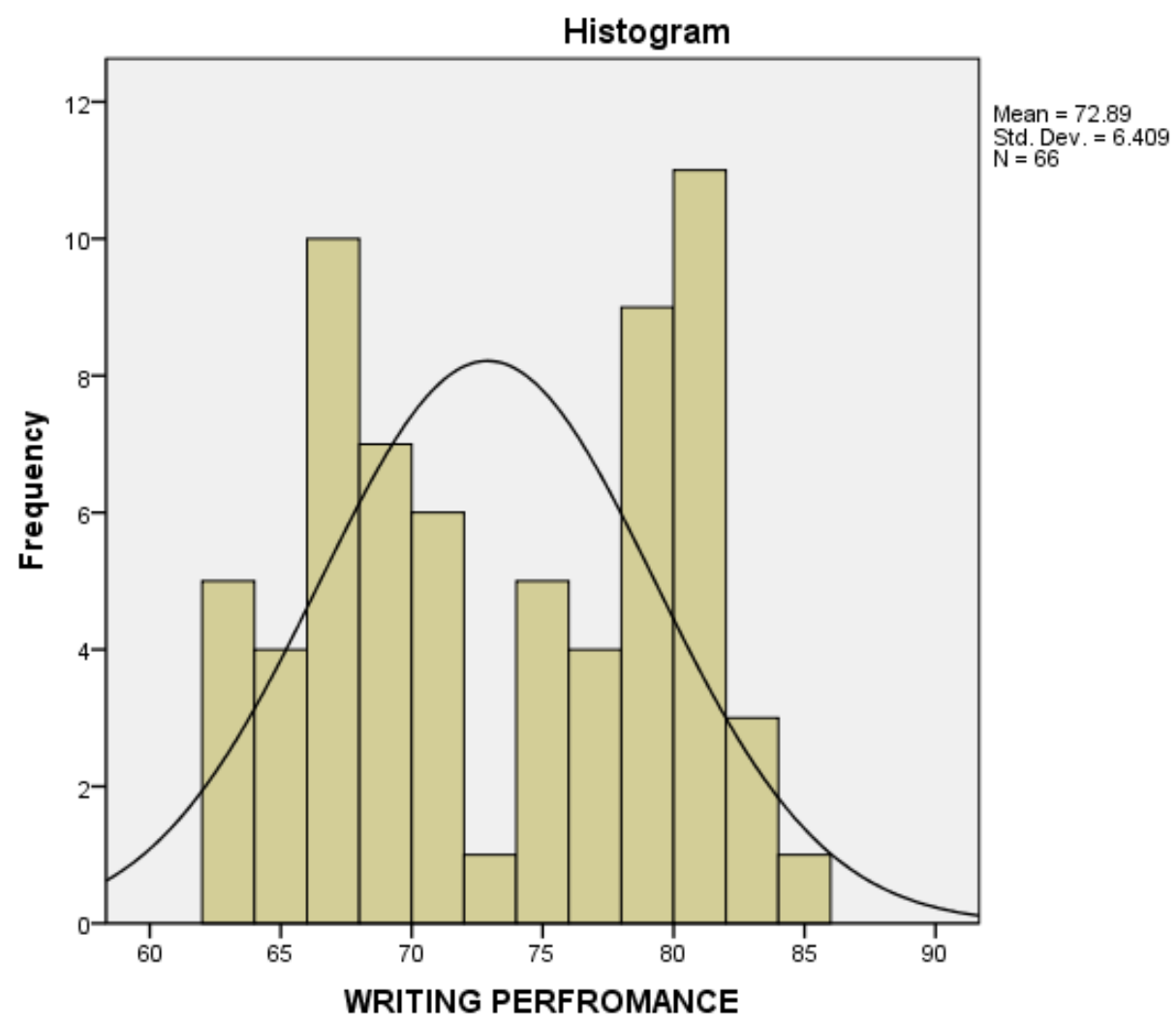

Based on the graphic above it can be assumed that the high frequency score on range of 80-85; on the other hand, the low frequency score on range 70-75 at the same time the form of curve forms like a bell; it means that variable data of writing performance is distributed in the normal position. Moreover, the description for questionnaire of writing apprehension can be seen below. 


Statistics
WRITING APPREHENSION
\begin{tabular}{|l|r|}
\hline \multicolumn{1}{|c|}{ Valid } & 66 \\
\multicolumn{1}{|c|}{ Missing } & 0 \\
Mean & 69.98 \\
Median & 69.00 \\
Mode & 68 \\
Std. Deviation & 7.050 \\
Variance & 49.707 \\
Range & 34 \\
Minimum & 50 \\
Maximum & 84 \\
Sum & 4619 \\
\hline
\end{tabular}

On the data above, it can be known from 66 responders the average score is 69,98 , the median score is 69.00 and the modus score is 68 , the maximum score is 84 and the minimum score is 50 so that the range is 34. And the standard deviation is 7,050 also the variance score is 49.707 .

By that description data above, it can be assumed with the histogram graphic as follows:

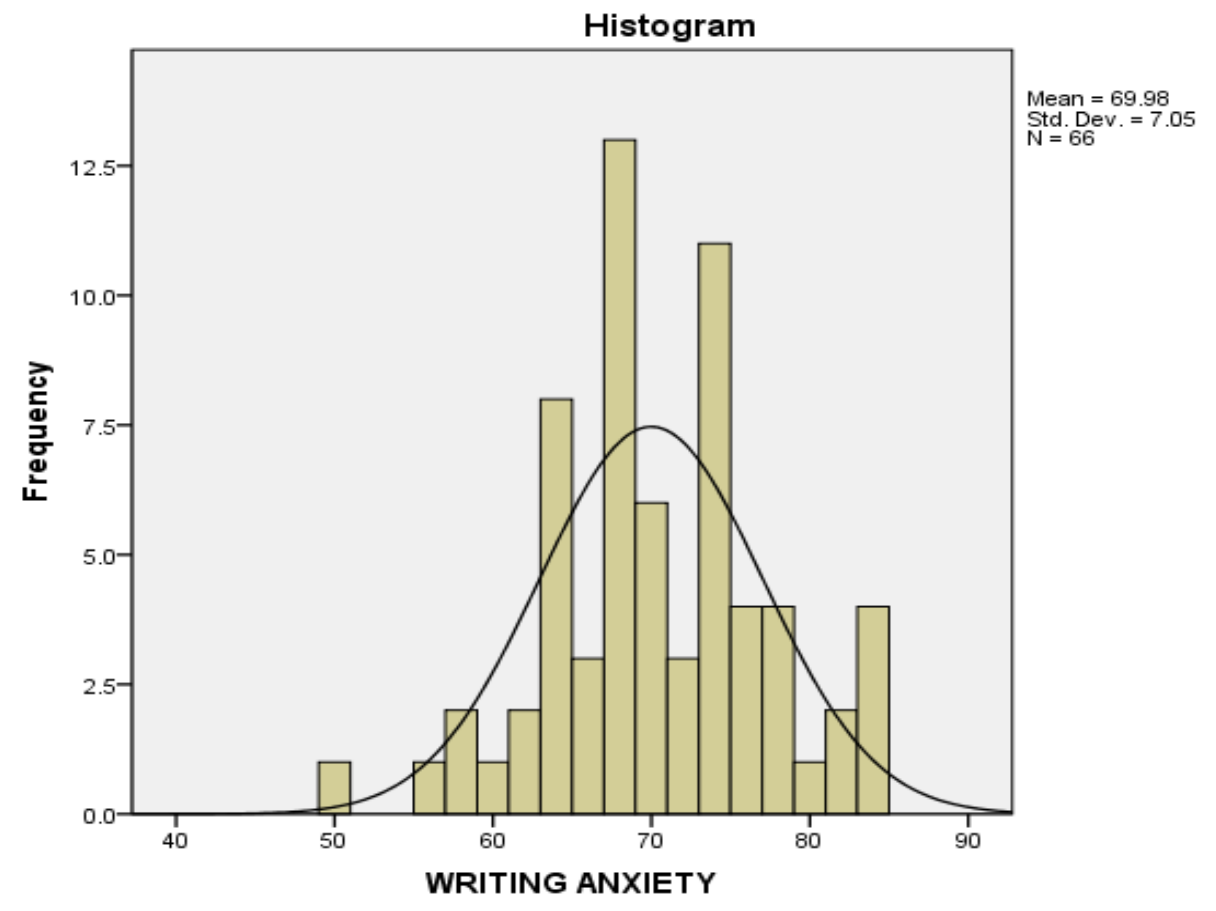

Based on the graphic data, it can be seen that the high frequency range on 6070 otherwise, the low frequency range is 50-60. For the curve forms such like a bell that means the variable data of writing apprehension is distributed as normal.
Furthermore, result of test of regression helped by SPPS 17.0 can be seen below. 
Variables Entered/Removed ${ }^{\mathbf{b}}$

\begin{tabular}{|l|l|l|l|}
\hline Model & $\begin{array}{l}\text { Variables } \\
\text { Entered }\end{array}$ & $\begin{array}{l}\text { Variables } \\
\text { Removed }\end{array}$ & Method \\
\hline 1 & WRITING & & Enter \\
& APPREHENSIO & & \\
& $\mathrm{N}^{\mathrm{a}}$ & & \\
\hline
\end{tabular}

a. All requested variables entered.

b. Dependent Variable: WRITING PERFORMANCE

\section{Model Summary}

\begin{tabular}{|c|c|c|c|c|}
\hline Model & $\mathrm{R}$ & R Square & $\begin{array}{ll}\text { Adjusted } & \mathrm{R} \\
\text { Square } & \end{array}$ & $\begin{array}{l}\text { Std. Error of the } \\
\text { Estimate }\end{array}$ \\
\hline 1 & $.127^{a}$ & .016 & .001 & 6.407 \\
\hline
\end{tabular}

a. Predictors: (Constant), WRITING APPREHENSION

ANOVA ${ }^{\mathbf{b}}$
\begin{tabular}{|l|r|r|r|r|r|}
\hline Model & Sum of Squares & df & Mean Square & F & Sig. \\
\hline $1 \quad$ Regression & 42.855 & 1 & 42.855 & 1.044 & $.311^{\mathrm{a}}$ \\
Residual & 2627.403 & 64 & 41.053 & & \\
Total & 2670.258 & 65 & & & \\
\hline
\end{tabular}

a. Predictors: (Constant), WRITING APPREHENSION

b. Dependent Variable: WRITING PERFORMANCE

\section{Coefficients $^{a}$}

\begin{tabular}{|c|c|c|c|c|c|c|}
\hline \multirow{2}{*}{\multicolumn{2}{|c|}{ Model }} & \multicolumn{2}{|c|}{ Unstandardized Coefficients } & $\begin{array}{l}\text { Standardized } \\
\text { Coefficients }\end{array}$ & \multirow[b]{2}{*}{$\mathrm{T}$} & \multirow[b]{2}{*}{ Sig. } \\
\hline & & $\mathrm{B}$ & Std. Error & Beta & & \\
\hline \multirow[t]{2}{*}{1} & (Constant) & 80.954 & 7.928 & & 10.211 & .000 \\
\hline & $\begin{array}{l}\text { WRITING } \\
\text { APPREHENSION }\end{array}$ & -.115 & .113 & -.127 & -1.022 & .311 \\
\hline
\end{tabular}

a. Dependent Variable: WRITING PERFORMANCE

Variables Entered/Removed ${ }^{\text {b }}$

\begin{tabular}{|l|l|l|l|}
\hline Model & $\begin{array}{l}\text { Variables } \\
\text { Entered }\end{array}$ & $\begin{array}{l}\text { Variables } \\
\text { Removed }\end{array}$ & Method \\
\hline 1 & WRITING & & Enter \\
& $\begin{array}{l}\text { APPREHENSIO } \\
\mathrm{N}^{\mathrm{a}}\end{array}$ & & \\
\hline
\end{tabular}

a. All requested variables entered.

b. Dependent Variable: WRITING PERFROMANCE

On this table, it can be stated that the independent variable ( $\mathrm{X}$ variable) that is writing apprehension can be named as the determiner variable for determining the high or low of writing performance score.

\section{Model Summary}

\begin{tabular}{|l|r|r|lr|lr|}
\hline Model & & R Square & $\begin{array}{l}\text { Adjusted } \\
\text { Square }\end{array}$ & R & $\begin{array}{l}\text { Std. Error of the } \\
\text { Estimate }\end{array}$ \\
\hline 1 & $.127^{\mathrm{a}}$ & .016 & & .001 & \multicolumn{2}{|c|}{6.407} \\
\hline
\end{tabular}

a. Predictors: (Constant), WRITING ANXIETY

On this table, it can be seen that the correlation (effect) between writing anxiety towards writing performance that is $(\mathrm{R}) 0,127$. It can be concluded that there is a weak correlation (none of significance correlation) due to $\mathrm{R}$ score is on the range $0,000-0,199$. 
Therefore, it can be summed up that the correlation between writing apprehension towards writing performance is very weak. Otherwise, the score of $\mathrm{R}$ square is coefficient determination that is independent variable contribution (writing apprehension) on determining the high or low dependent variable (writing

\begin{tabular}{|c|c|c|c|c|c|c|}
\hline & & Sum of Squares & $\mathrm{df}$ & Mean Square & $\mathrm{F}$ & Sig. \\
\hline \multirow[t]{3}{*}{1} & Regression & 42.855 & 1 & \multirow{3}{*}{$\begin{array}{l}42.855 \\
41.053\end{array}$} & \multirow[t]{3}{*}{1.044} & \multirow[t]{3}{*}{$.311^{a}$} \\
\hline & Residual & 2627.403 & 64 & & & \\
\hline & Total & 2670.258 & 65 & & & \\
\hline
\end{tabular}

a. Predictors: (Constant), WRITING APPREHENSION

b. Dependent Variable: WRITING PERFROMANCE

On this table, it is stated the regression significance that is $\mathrm{F}$ score 1,044 , and for significance score is 0,311 that is far from 0,05 . Because the significance score is over than 0,05 , it

\begin{tabular}{|c|c|c|c|c|c|c|}
\hline \multirow{2}{*}{\multicolumn{2}{|c|}{ Model }} & \multicolumn{2}{|c|}{ Unstandardized Coefficients } & $\begin{array}{l}\text { Standardized } \\
\text { Coefficients } \\
\end{array}$ & \multirow[b]{2}{*}{$\mathrm{T}$} & \multirow[b]{2}{*}{ Sig. } \\
\hline & & $\mathrm{B}$ & Std. Error & Beta & & \\
\hline \multirow[t]{2}{*}{1} & (Constant) & 80.954 & 7.928 & & 10.211 & .000 \\
\hline & $\begin{array}{l}\text { WRITING } \\
\text { APPREHENSION }\end{array}$ & -.115 & .113 & -.127 & -1.022 & .311 \\
\hline
\end{tabular}

a. Dependent Variable: WRITING PERFORMANCE

On the table, it can be seen that the regression equation displayed:

Note :

$$
\mathrm{Y}=80.954+(-0,115) \mathrm{X}
$$

80.954 : If there is no the flowing or rising on the writing apprehension score, the writing performance score is staying on the score 80,954

$-0,115$ : If there is the rising score 1 point on the writing apprehension score, the writing performance score will flow on the score 0,115 , because the result is negative; if the writing anxiety score is rising, the writing performance is flowing.

The $t$ score is $-1,022$, on the other hand the significance score is 0,311 that is very over from 0,05 . Because the performance), in this research the score is 0,016 if presented in percent is $1,6 \%$. Therefore, it can be stated that writing apprehension contribution on determining writing performance is $1.6 \%$, meanwhile the rest $98,4 \%$ is determined by other factors out of writing apprehension. means that $\mathrm{H}_{\mathrm{o}}$ is accepted or it can be said there is no correlation between writing apprehension towards writing performance. 
can be named as good quality of writing performance. Meanwhile, the average score of writing apprehension goes to 69.98. This indicates that the students were relatively not anxious when they wrote the task on the test. The class atmosphere did not give them pressure to feel anxious about what and how they write even though they were asked to write an academic paper. In fact, they fulfilled the task on test on time and the quality of the paper they write was seemingly good. This result can be understandable probably because the respondents taken on the research were advanced learners of writing subject.

Furthermore, from the regression equation, it can be known that there is a negative result (coefficient) on writing apprehension. It indicates that the higher writing apprehension score, the lower writing performance. This finding is consistent with the result findings showed by Al_Sawalha et al in Malaysia. They summed up noted that EFL students experienced high level of writing apprehension. They find writing to be unrewarding and will avoid classes that give writing task (Al_Sawalha, Salem, Chow, \& Foo, 2012). Then, Takahashi's research in Japan wrote that students with better writing skills, who probably experienced lower levels of writing apprehension, had higher overall English proficiency; then they have also scored higher in the final examination. The result of this study also supports that writing apprehension was found to be negatively related to class achievement/proficiency for Japanese EFL students (Takahashi: 2010).

Based on $t$ test score, it can be concluded that there is no significant correlation between writing apprehension and writing performance particularly for academic writing in higher education level. This finding was not the same as study by Erkan and
Saban (2011) in Turkey. Their research showed that writing apprehension directly affects writing performance.

\section{CONCLUSION}

This present study was intended to find out the correlation between writing apprehension and writing performance particularly for academic writing in higher education level. After having surveyed 66 respondents by giving them writing test and questionnaire, the researchers then analyzed the data quantitatively helped by SPSS 17.0.

The result showed that the average score of writing performance was 72 ; on the other hand, average of writing apprehension scored 69.98. This indicates that the quality of paper made by the students was apparently good. Meanwhile, the writing apprehension score shows that the students do not feel very anxious during writing test.

Moreover, the $t$ score (-1.22) and the significant score $(0.0311)$ were very on top of the sig. score (0.05). It can be said that $\mathrm{H}_{0}$ is accepted and $\mathrm{H}_{\mathrm{a}}$ is rejected. We can draw a conclusion that there is no significant correlation between writing apprehension and writing performance for academic writing in higher education level.

\section{BIBLIOGRAPHY}

Al-Sawalha, Salem, M. A., Chow, \& Foo, T. V. (2012). The Effects of Writing Apprehension iin English on the Writing Process of Jordanian EFL Students at Yarmouk University. International Interdisciplinary Journal of Education, 1 (1), 6-14.

Cheng, Y. S. (2004). A measure of Second Language Writing Anxiety: Scale Development and 
Preliminary Validation. Journal of Second Language Writing 13, 313-335.

Daly, John A.\& Wilson, D.A. 1983. Writing Apprehension, SelfEsteem, and Personality. Research in the teaching of English 17.4:327-341

Erkan D.Y, \& Saban, A.I. 2011. Writing Performance Relative to Writing Apprehension, Self-Efficacy in Writing, and Attitudes towards Writing: A Correlational Study in Turkish Tertiary-Level EFL. EFL Asian Journal, March 2011 first quarterly, 164-192

Jahin, J. H. (2012). The Effect of Peer Reviewing on Writing Apprehension and Essay Writing Ability of Prosfective EFL Teachers. Australian Journal of Teacher Education, 37(11), 6084.

Oshima, A., \& Hogue, A. (2006). Writing Academic English,
Fourth Edition. New York: Pearson Education, Inc.

Parina, J. M., \& de Leon, K. (2013). The Significance of Language Exposure with Writing SelfEfficacy and Writing Apprehension of Filipino ESL Writers. Philippine ESL Journal, (10), Feb, 232-244.

Shah, P. M., Mahmud, W. W., Din, R., Yusof, A., \& Pardi, K. M. (2011). Self-efficacy in the Writing of Malaysian ESL Learners. World Applied Sciences Journal 15 (Innovation and Pedagogy for Lifelong Learning, 8-11.

Takahashi, A. (2010, July (15)). Foreign Language Writing Apprehension: Its relationship with Motivation, Self-perceived Target Language Ability, and Actual Language Ability. Niigata Univerity of Bahasa dan Budaya , 89- 100. 